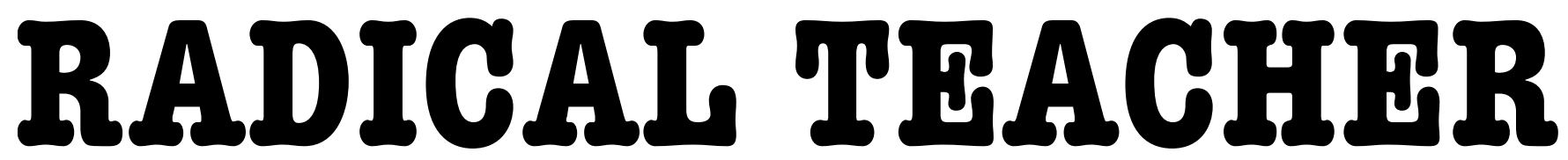

A SOCIALIST, FEMINIST, AND ANTI-RACIST JOURNAL ON THE THEORY AND PRACTICE OF TEACHING

\title{
In Memoriam: Jim Miller
}

By Jeffrey Melnick

for the Radical Teacher Editorial Board

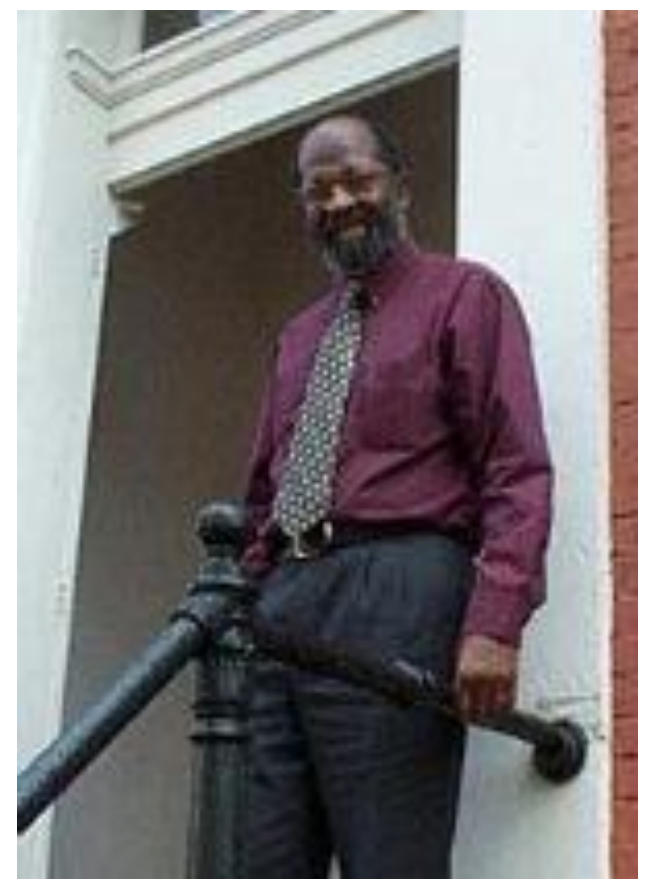
PHOTO OF JIM MILLR
COURTESY OF GEORGE WASHINGTON UNIVERSITY 
I $t$ is with great sorrow that we note the death of James A. Miller, Radical Teacher board member in the early 1990s (during his tenure as a beloved member of Trinity College's faculty) and then as a comrade-at-adistance when he moved to University of South Carolina and ultimately George Washington University. Jim embodied a number of phrases that we too often toss around blithely: he was a public intellectual in a meaningful way, bringing his expertise in African American literature and culture to high school students in Washington, DC and to readers of his book reviews in the Boston Globe, Washington Post, and elsewhere; he was an interdisciplinary and transnational scholar, who insisted consistently that it is indefensible-impossible, really-to study literature, music, and history as distinct arenas of social and cultural activity.

And perhaps most important of all, he was a committed teacher and mentor. Jim was regularly involved with the School Without Walls High School on the campus of GWU, but it is better to understand his entire life and career as being captured by the phrase "school without walls." Jim was teaching all the time, and anyone who knew him at all knows that his commitment to mentoring younger scholars and teachers was tireless. I knew Jim during the four years I taught at Trinity College and was always impressed by his selflessness. Jim was always connecting people, promoting younger scholars to colleagues he thought might be interested in their work, making suggestions for how to engage more fully in the field and in the profession more generally. I know that I am one of a large number of people who benefitted from Jim Miller saying "I've got my eye on you." As a young teacher and scholar working in an adjunct position at Trinity I was constantly amazed at Jim Miller's willingness to read my work, make suggestions for conferences to attend, and introduce me to major players in African American, literary, and cultural studies.

And then there was another special blessing: during one of my semesters at Trinity, Jim was on leave, and rather than leave his office unused, he generously agreed to let me camp out there for the term. It is not even the slightest exaggeration to say that a crucial part of my education took place among Jim Miller's books: I spent countless hours digging into his library, learning from individual volumes, of course, but most of all learning that it all matters. Jim's intellectual breadth was remarkable; this shows in his own scholarship of course (from his dissertation on Richard Wright in 1976 to his book on the cultural legacies of Scottsboro in 2009). After living through a graduate education in American Studies during which the chair of my department had insisted to me that popular music was a "hobby" and not a proper object of study, it was incredibly energizing to come to know Jim Miller who knew that we could not even begin to do the work of American Studies without attending to the central role played by popular music-its texts, its players, its institutions. I learned not only from the content of Jim's library but also the form: the shambly abundance of his office made it clear to me that if you are going to do this kind of work seriously, there will have to be some piles of books on the floor, some piled on top of already stuffed-tothe-max bookcases.

Jim Miller received his Ph.D in 1976 from the State University of New York at Buffalo, after completing his undergraduate work at Brown University (Providence was his hometown). From the time he completed his doctorate until his retirement, Jim taught courses on African American literature and culture at numerous American institutions and in Johannesburg as well. In addition to his Scottsboro book, he also published numerous essays, edited a book on approaches to teaching Richard Wright, and introduced an amazing book of photographs by the twin brothers Morgan and Marvin Smith. In the 2000s, Jim turned his attention particularly to Black life in Washington, D.C., and published a number of significant essays on the subject. Jim often said that his most important intellectual influence was Ralph Ellison, whom he met at Brown during his undergraduate days, and it shows: like Ellison (and Ellison's acolyte Albert Murray), Jim was consistently engaged in a battle to uncover the complexly hybrid roots of American literary and musical culture.

Jim was an ambitious scholar who crossed all kinds of lines. But he was also, as one Radical Teacher board member put it, "a political realist who reminded us of our limits, warned against building our politics around other people's revolutions, and could be counted on for a skeptical word or two about heroes." Jim Miller: a political realist who insisted on the high stakes of scholarly inquiry and public engagement. The editorial board of Radical Teacher mourns the loss of our colleague and friend and takes some measure of comfort in the example his work continues to set for us all. (c) BY-NC-ND

ULIS D-Serle
This work is licensed under a Creative Commons Attribution-Noncommercial-No Derivative Works 3.0 United States License.

This journal is published by the University Library System of the University of Pittsburgh as part of its D-Scribe Digital Publishing Program, and is cosponsored by the University of Pittsburgh Press.
RADICAL TEACHER 